\title{
The Impact of Replacement Windows on Air Infiltration and Indoor Air Quality in Dwellings
}

\author{
I Ridley, J Fox, T Oreszczyn and S H Hong \\ Bartlett School of Graduate Studies \\ University College London
}

\begin{abstract}
This paper examines the impact on domestic background air infiltration of replacing 'old windows' with modern double-glazed and draught sealed windows, both with and without controllable ventilation (e.g. trickle ventilators). Methods of estimating the change in infiltration rate produced by such a window replacement are reviewed. A simple model has been developed which, using laboratory measurements of window air permeability, predicts the reduction in infiltration that can be expected when a given number of windows are replaced in a dwelling. The validity of the model has been tested using data from a house both before and after replacing the windows. The paper investigates the impact that replacing windows in the UK domestic building stock (partly stimulated by Part L of the Building Regulations in England and Wales) is likely to have on the adequate provision of ventilation in the domestic stock. The paper concludes that replacing old windows in a significant proportion of UK dwellings can reduce ventilation levels below recommended levels unless controllable background ventilation is installed at the same time as new windows.
\end{abstract}

Key words: air infiltration, background ventilation, replacement windows, dwellings, building retrofit.

\section{Introduction}

The energy efficient refurbishment of the existing building stock is essential if developed countries are to meet their commitments to reduce the emissions of carbon dioxide, a principle greenhouse gas. Replacing existing windows with modern energy efficient windows is one of the measures that can easily be introduced into existing buildings. For this reason Part L of the 2002 Building Regulations for England and Wales, which covers energy efficiency, brings for the first time, domestic replacement windows under its control, see Annex A. This introduces the problem of getting the correct balance between energy efficiency and providing adequate ventilation to the existing building stock.

In the UK existing dwellings have been traditionally considered as leaky with unnecessary ventilation resulting in excessive energy use. However care must be taken that, just as in new buildings, adequate controllable background ventilation is provided. This is particularly the case in buildings, which already have poor indoor air quality. For this reason Part L of the Building Regulations refer to Part $\mathrm{F}$ of the regulation, which covers the provision of adequate ventilation. However there is no explicit mention that Part $\mathrm{F}$ always applies to refurbishment just that, after any refurbishment, the building should "not have a worse level of compliance". This has been interpreted by some to mean that if a window had no controllable background ventilation before replacement then the new replacement window does not require any. Others have interpreted the regulations to mean that, if replacement windows are likely to significantly reduce a building's background ventilation to levels which may result in poor indoor air quality, then controllable background ventilation must be introduced at the same time as a window is replaced. This paper explores the impact that these two different interpretations of the regulations is likely to have and whether there will be adequate ventilation for health and moisture control.

\section{Recommended and Typical Background Ventilation in Dwellings}

Recommended levels of background ventilation in dwellings are based predominately on the requirement to disperse moisture generated in dwellings. In areas where combustion occurs higher levels are required. The principle reason for controlling moisture is to prevent mould growth, which has been associated with a range of health problems. Mould growth occurs on hygroscopic building surfaces when the relative humidity at the surface is above $80 \%$ for a period of several weeks 
(Oreszczyn, 2000). Because external walls are colder than the air inside the building the relative humidity is higher at wall surfaces than the bulk of the room. In order to avoid mould growth a general room $\mathrm{RH}$ of less than $70 \%$ is recommended provided the building has no serious cold bridges. Relative humidity is a function of temperature and moisture. It is therefore possible to control the room $\mathrm{RH}$ by either raising the temperature or reducing the moisture. Improving the heating system and insulation can raise the internal temperature; moisture levels can be reduced by either reducing sources of moisture or increasing the ventilation.

BRE (BRECSU, 1997) recommend a ventilation rate of between 0.5 ach and 0.7 ach as being adequate to control most indoor pollutants and provide sufficient fresh air for the comfort of occupants. In another guide (BRECSU, 1996) BRE state a minimum whole house ventilation rate of 0.5 ach is generally considered suitable for condensation protection. This is derived from both practical and theoretical experience. Theoretically it is possible to examine the impact of a reduced air infiltration rate using the moisture balance equations in BS5250 (2002) and the temperature equations in BREDEM 8 (Anderson et al (1997)). Figure 1 shows how the internal relative humidity (RH) varies with ventilation for an example property with two types of occupant, fuel poor and fuel rich. In the case of fuel rich occupants as the ventilation rate increases they can afford to maintain a comfortable temperature in the dwelling and hence the $\mathrm{RH}$ always reduces. In fuel poor dwellings as the ventilation increases the temperature drops in the property because the occupants cannot afford to adequately heat the property. The net result of this is that the RH increases at above 1 ach.

Stephen (1998) has published data on the distribution of background infiltration rates in UK dwellings, as measured by the Building Research Establishment (BRE), see Figure 2. The average infiltration rate during pressure testing at $50 \mathrm{~Pa}$ was found to be $13.1 \mathrm{ach}$. Applying the standard rule of thumb to convert from pressure test results $\left(\mathrm{ACH}_{50}\right)$ to air infiltration at normal operational pressure (NL), as given by Sherman (1998)

$N L=\frac{A C H_{50}}{20}$

The average heating season background air infiltration rate, of a UK dwelling is 0.7 ach. For simplicity throughout this paper Equation 1, has been used to convert pressure test results to air infiltration at normal operational pressures. However it must be noted that if the flow coefficient, flow exponent, floor area and height of a dwelling are known, the background infiltration rate can be calculated with greater accuracy using Equations 2 and 3 below.

$$
E L A_{50}=\kappa 50^{n-0.5} \sqrt{\frac{\rho}{2}}
$$

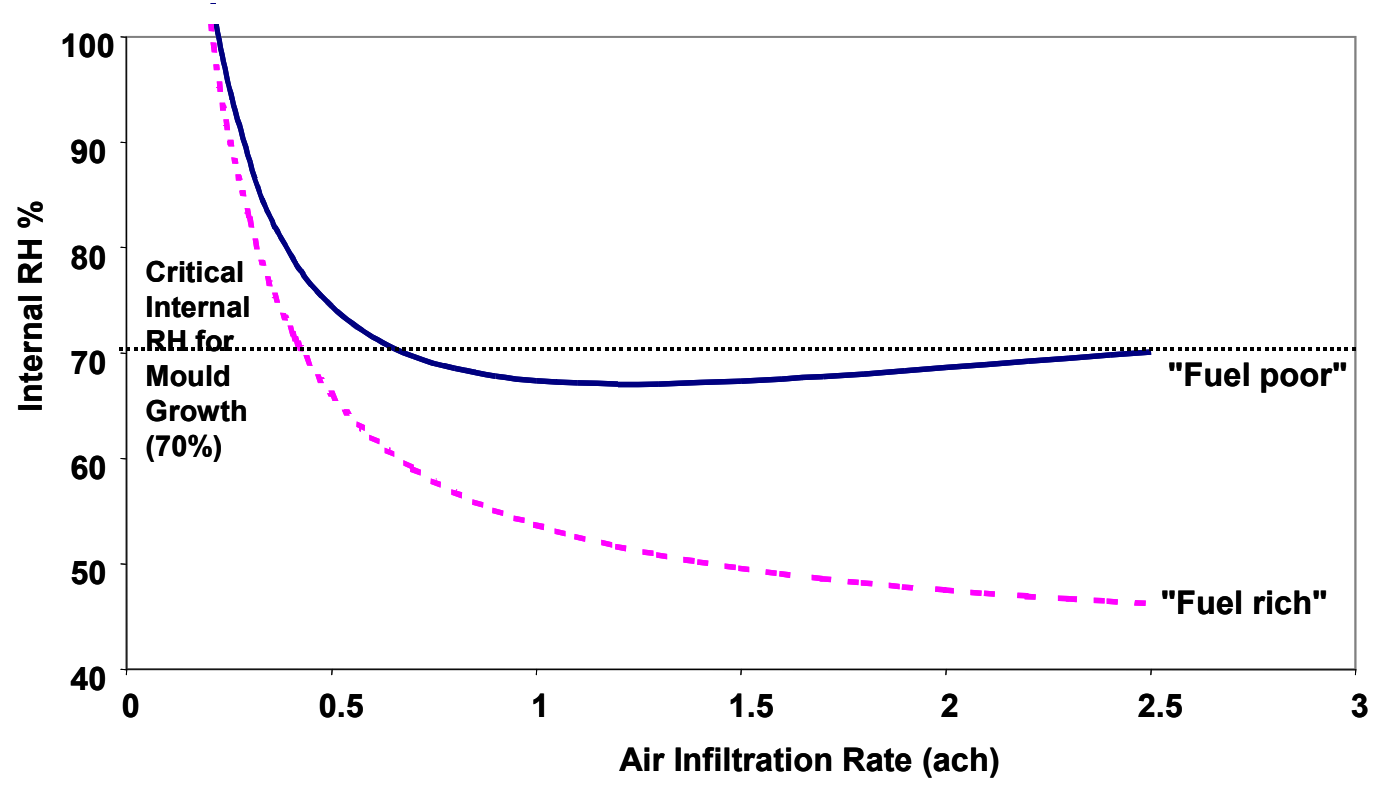

Figure1. The impact of ventilation, on internal relative humidity, for both "Fuel Poor" and "Fuel Rich" occupants 


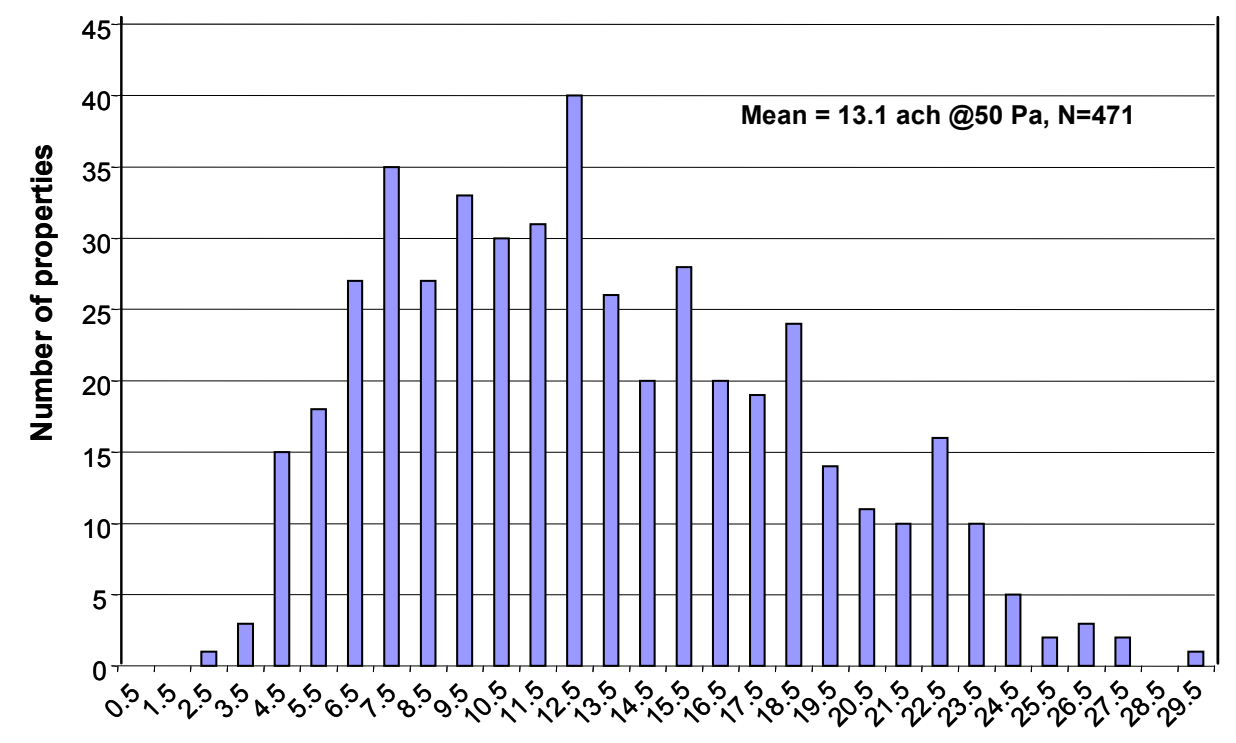

Air leakage rate, air changes per hour @ 50

Figure 2. Measured air leakage at 50 Pa in 471 dwellings in the UK. Source Stephen (1998)

$$
N L=1000 \frac{E L A_{50}}{A_{f}}\left(\frac{H}{2.5}\right)^{0.3}
$$

where, $\mathrm{ELA}_{50}$ is the effective leakage area at $50 \mathrm{~Pa}, \kappa$ is the house flow coefficient, $\mathrm{n}$ is the house flow exponent, $\mathrm{H}$ is the height of the house and $\mathrm{A}_{\mathrm{f}}$ the floor area.

Some $34 \%$ of properties tested had a theoretical operational air infiltration rate below 0.5 ach i.e. less than 10 ach at $50 \mathrm{~Pa}$ and hence likely to suffer from poor air quality.

\section{Methods of Estimating Background Air Infiltration due to Windows}

There are several methods, both empirical and theoretical, which can be used to calculate the air infiltration rate through specific building components. There are also some simple rule of thumb models that are suitable for calculating the change in infiltration rate of a building when windows are replaced.

The BRE Domestic Energy Model BREDEM-8 (Anderson et al 1997) calculates the infiltration rate using the following algorithm: $n_{i}=\sum L_{i}+\sum W_{i} p_{i}+\frac{\sum N_{i} F_{i}}{V_{T}}$

where: $L_{\mathrm{i}}$ is a fabric leakage component (ach)

$\mathrm{W}_{\mathrm{i}}$ is a window leakage component (ach)

$\mathrm{P}_{\mathrm{i}}$ is the proportion (by area) of windows of a given type

$\mathrm{N}_{\mathrm{i}}$ is the number of items (fans, vents etc) of a given type

$F_{i}$ is the flow rate for items (fans vents etc) of a given type $\left(\mathrm{m}^{3} /\right.$ hour $)$

$\mathrm{V}_{\mathrm{T}}$ is the total house volume $\left(\mathrm{m}^{3}\right)$

The leakage components for window elements are given in Table 1.

Hence if all windows are changed from being very loose and unsealed to well fitting and sealed, the predicted decrease in infiltration rate is $0.3 \mathrm{ach}$. The algorithm used to calculate window infiltration in the Standard Assessment Procedure SAP version 9.61 uses the following: window infiltration $=0.25$ [0.2* Percentage of windows draught stripped $/ 100 \%]$. Hence the change in infiltration rate due to draught stripping all windows is $0.2 \mathrm{ach}$.

Stephen (1998) reports on the results of pressure testing 471 UK dwelling, and states that between $16 \%$ to $44 \%$ of the total infiltration into a house is 
due to windows and doors, and that a further $2 \%$ is due to gaps between window frames and walls. The average infiltration rate of a UK house was found to be $0.7 \mathrm{ach}$. Assuming that $16 \%$ of this was due to infiltration from windows and doors, this would suggest a $\mathrm{W}_{\mathrm{i}}$ of $0.1 \mathrm{ach}$.

In a recent survey examining the effectiveness of the Warmfront energy efficiency programme (Hong,
2002), 78 houses were pressure tested and extensively surveyed. Table 2 shows the impact of dwelling draught stripping and adding new double glazed windows on the background air infiltration rate, (assuming the divide by 20 conversion of pressure test results at $50 \mathrm{~Pa}$ ). These results suggest, whereas dwelling draught stripping appears to have little effect on the background infiltration rate, the average infiltration rate of houses with full double

Table 1. Air infiltration associated with different building components. Source Anderson (1997)

\begin{tabular}{|l|l|}
\hline Windows and doors & $\mathbf{W}_{\mathbf{i}}$ Infiltration contribution (ach ) \\
\hline if all unopenable & 0.02 \\
\hline if all well fitting and draught sealed & 0.05 \\
\hline if all loose and draught sealed & 0.1 \\
\hline if all tight but not draught sealed & 0.15 \\
\hline if all loose & 0.25 \\
\hline if all very loose & 0.35 \\
\hline
\end{tabular}

Table 2. The impact of a range of energy efficient measures on measured air infiltration. Source Hong (2002)

\begin{tabular}{|c|c|c|c|}
\hline \multicolumn{2}{|c|}{ Comparison Cases } & $\begin{array}{c}\text { Mean background air } \\
\text { infiltration } \\
\text { (ach) }\end{array}$ & Number \\
\hline \multirow{3}{*}{ Draught Stripping } & None & 0.68 & 6 \\
\cline { 2 - 4 } & Partial & 0.78 & 18 \\
\cline { 2 - 4 } & Full & 0.71 & 56 \\
\hline \multirow{3}{*}{ Double Glazing } & None & 0.90 & 17 \\
\cline { 2 - 4 } & Partial & 0.73 & 23 \\
\cline { 2 - 4 } & Full & 0.64 & 38 \\
\hline
\end{tabular}

Table 3. Measured Effective Leakage Areas of 64 windows. Source Shapiro and James (1997)

\begin{tabular}{|l|c|c|l|l|l|l|}
\hline & $\begin{array}{l}\text { Original } \\
\text { Tight }\end{array}$ & $\begin{array}{l}\text { Original } \\
\text { Average }\end{array}$ & $\begin{array}{l}\text { Original } \\
\text { Loose }\end{array}$ & $\begin{array}{l}\text { Replacement } \\
\text { Sash }\end{array}$ & $\begin{array}{l}\text { Vinyl } \\
\text { Window } \\
\text { Insert }\end{array}$ & $\begin{array}{l}\text { Original } \\
\text { sash } \\
\text { with } \\
\text { Vinyl } \\
\text { Jamb } \\
\text { Liners }\end{array}$ \\
\hline $\begin{array}{l}\text { Number } \\
\text { of } \\
\begin{array}{l}\text { Windows } \\
\text { tested }\end{array}\end{array}$ & 35 & 35 & 47 & 11 & 14 & 37 \\
\hline $\begin{array}{l}\text { ELA total } \\
\text { (sq } \\
\text { inches) }\end{array}$ & 0.86 & 1.48 & 2.78 & 0.75 & 0.29 & 1.85 \\
\hline
\end{tabular}


glazing is 0.26 ach lower than the average of houses with no double glazing.

ASTM E783-93 (American Society for Testing and Materials, 1994) is a test method for field measurements of air leakage through installed exterior windows. Shapiro and James (1997) have used a modified version of this standard to measure the effective leakage areas of 64 old windows of different configurations. Their results are summarised in Table 3.

Infiltration may be modelled using software such as CONTAMW and COMIS (Axley, 1995, Warren, 2000). Such infiltration models are based on an empirical (power law) relationship between the flow and the pressure difference across a crack or opening in the building envelope:

$Q=C\{\Delta P\}^{n}$

where: $\mathrm{Q}=$ Flow $\left(\mathrm{m}^{3} / \mathrm{s}\right)$

$\mathrm{C}=$ Flow Coefficient

$\Delta \mathrm{P}=$ Pressure difference across the opening $(\mathrm{Pa})$

$n$ = Flow Exponent

If the flow characteristics, the flow coefficient and exponent, of a building element are known, either from experiment or from tabulated values, the infiltration due to the element may be calculated as a function of pressure difference. Liddament (1986) tabulates the flow characteristics of different window configurations and frame types. Such equations can be used to directly model the flow through elements when a $50 \mathrm{~Pa}$ pressure difference is imposed, as during a fan pressurisation test. Modern windows are routinely tested to measure air infiltration according to BS 5368. Such tests can be used to calculate the flow coefficient and flow component of windows. Figure 3 shows results from a laboratory test of three different types of window. The graph clearly shows how the addition of draught stripping to an existing window still results in significant air leakage. The measured flow coefficient and exponent can then be used to determine the impact of a new window in situ.

\section{Replacement Window Infiltration Rate Equation}

For a house with old windows the following equation determines the whole house air exchange rate at $50 \mathrm{~Pa}$ :
$F_{o}=X+N C_{o}(50)^{n_{o}}$

where,

$\mathrm{F}_{\mathrm{o}}=$ Total Flow of air into house during pressurisation test at $50 \mathrm{~Pa}\left(\mathrm{~m}^{3} / \mathrm{s}\right)$

$\mathrm{X}=$ Flow from all other sources other than windows $\left(\mathrm{m}^{3} / \mathrm{s}\right)$

$\mathrm{N}=$ Number of windows

$\mathrm{C}_{\mathrm{o}}=$ Flow coefficient of old windows

$\mathrm{n}_{\mathrm{o}}=$ Flow exponent of old windows

The background air infiltration rate at normal domestic operating pressures can be estimated by dividing the total air flow into the house by the house volume and a factor of 20 , therefore:

$A_{o}=F_{o} * \frac{3600}{20 V}$

where, $A_{0}=$ Air Change rate of house with old windows (ach)

Similarly when new windows replace the old windows:

$F_{n}=X+N C_{n}(50)^{n_{n}}$

$A_{n}=F_{n} * \frac{3600}{20 V}$

Hence for the two cases we have the two equations:

$\frac{20 V A_{o}}{3600}=X+N C_{o}(50)^{n_{o}}$

$\frac{20 V A_{n}}{3600}=X+N C_{n}(50)^{n_{n}}$

The flow from all other sources $\mathrm{X}$ can be eliminated by subtracting Equation 11 from Equation 8 to gives

$\frac{20 V\left(A_{o}-A_{n}\right)}{3600}=N\left[C_{o}(50)^{n_{o}}-C_{n}(50)^{n_{n}}\right]$

Equation 12 can be simplified by assuming that the new windows are very airtight, and hence, $C_{n}$, the flow coefficient of the new window is small. This assumption can be justified from measurements made on pressure tests rigs (complying to BS 5368, 
see Figure 6.), in which the average value of $C_{n}$ for a new window is of the order of 0.00002 , whereas $C_{o}$ for old windows is of the order of 0.002 . Since $C_{n}$ is two orders of magnitude smaller than $C_{0}, C_{n}$ will have a negligible impact hence:

$$
\frac{20 V\left(A_{o}-A_{n}\right)}{3600}=N C_{o}(50)^{n_{o}}
$$

or $\left(A_{o}-A_{n}\right)=\frac{180 N C_{o}(50)^{n_{o}}}{V}$

Therefore knowing the number of windows to be replaced, the volume of the house and the flow characteristics of the old windows, the change in the air infiltration rate of replacing old windows with new can be estimated. If we assume that the flow

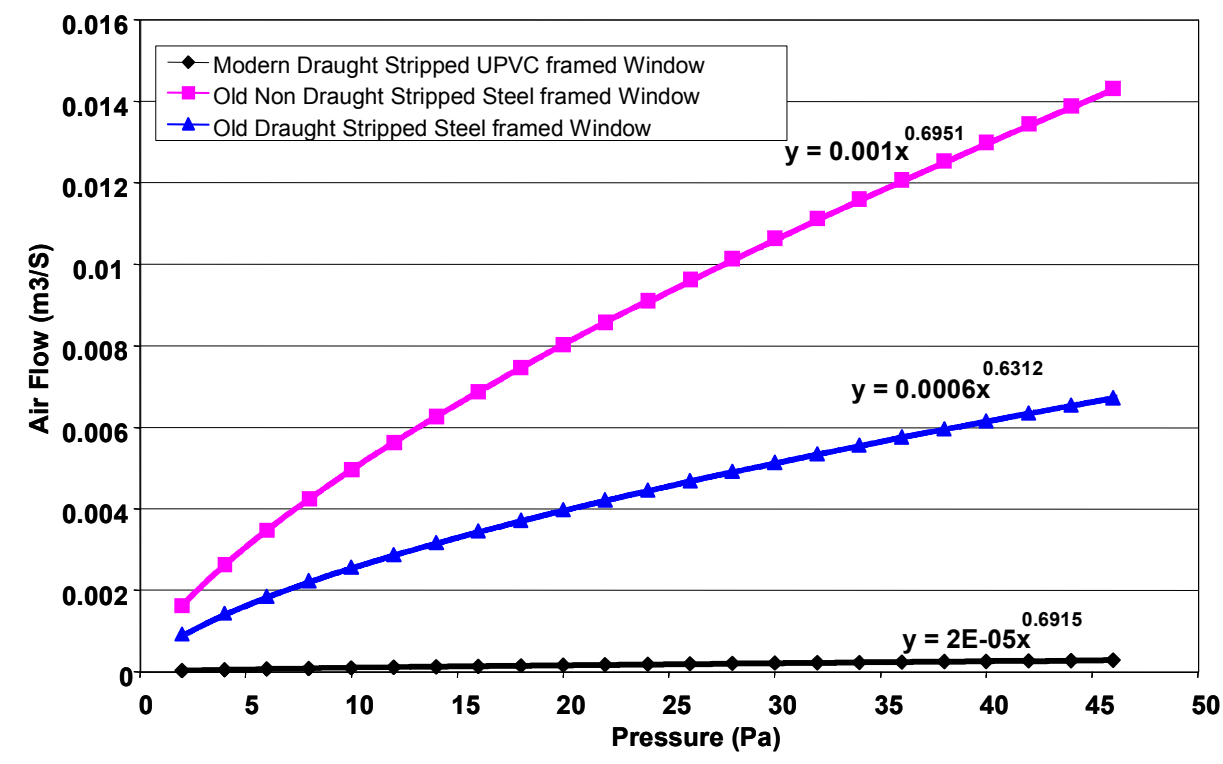

Figure 3. Comparison of the flow characteristics of old and new windows

Change in Infiltration ach
\begin{tabular}{|l|}
\hline $0.6-0.8$ \\
$\mathbb{0} 0.4-0.6$ \\
$\square 0.2-0.4$ \\
$\square 0-0.2$ \\
\hline
\end{tabular}

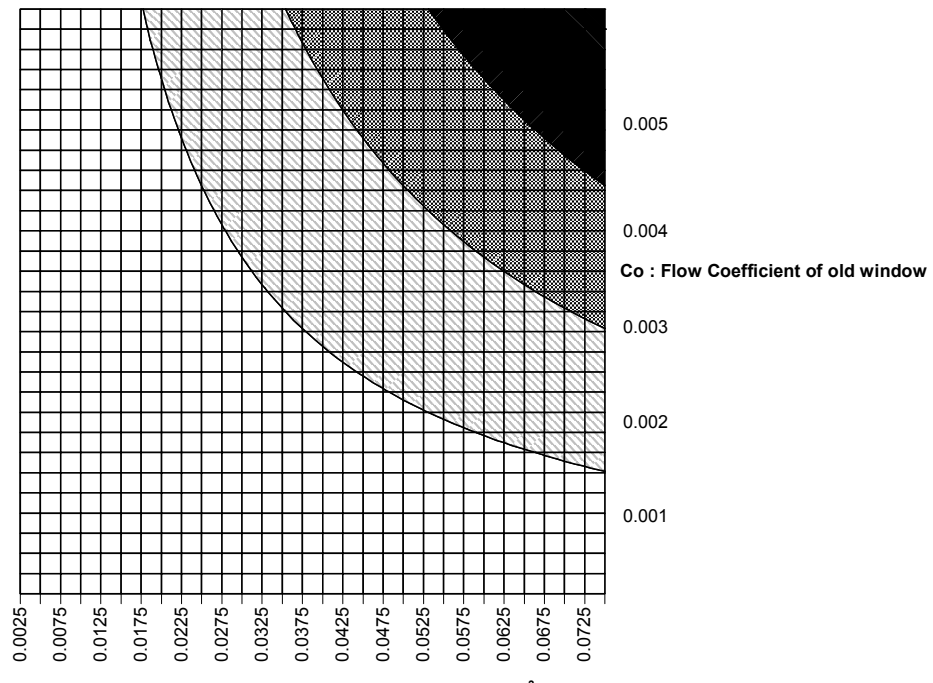

Figure 4. Predicted change in background infiltration rate due to replacing windows as a function of number of windows replaced, house volume and flow coefficient of old windows 
exponent for windows is equal to 0.6 , i.e. that of a thin crack, this further simplifies to

$$
\left(A_{o}-A_{n}\right)=1882\left(\frac{N}{V}\right) C_{o}
$$

Equation 12 can then be used to calculate the air infiltration as a function of $\mathrm{N} / \mathrm{V}$, the number of windows to be replaced divided by the volume of the house. Figure 4 shows the change in infiltration resulting from replacing windows as a function of $\mathrm{N} / \mathrm{V}$ and $\mathrm{C}_{\mathrm{o}}$. The graph shows that a significant reduction in air infiltration rate, greater than $0.2 \mathrm{ach}$, will be achieved if 8 windows with flow coefficient greater than 0.003 , are replaced in a house with a volume of $200 \mathrm{~m}^{3},(\mathrm{~N} / \mathrm{V}=0.04)$.

It is possible to determine the change in air infiltration resulting from the introduction of trickle ventilators to a house with new windows when the flow coefficient and exponent have been measured in accordance with CEN/TC 156 prEN 13141-1 (CEN/TC 156, 2002).

$$
\left(A_{t}-A_{n}\right)=180\left(\frac{T}{V}\right) C_{t}(50)^{n_{t}}
$$

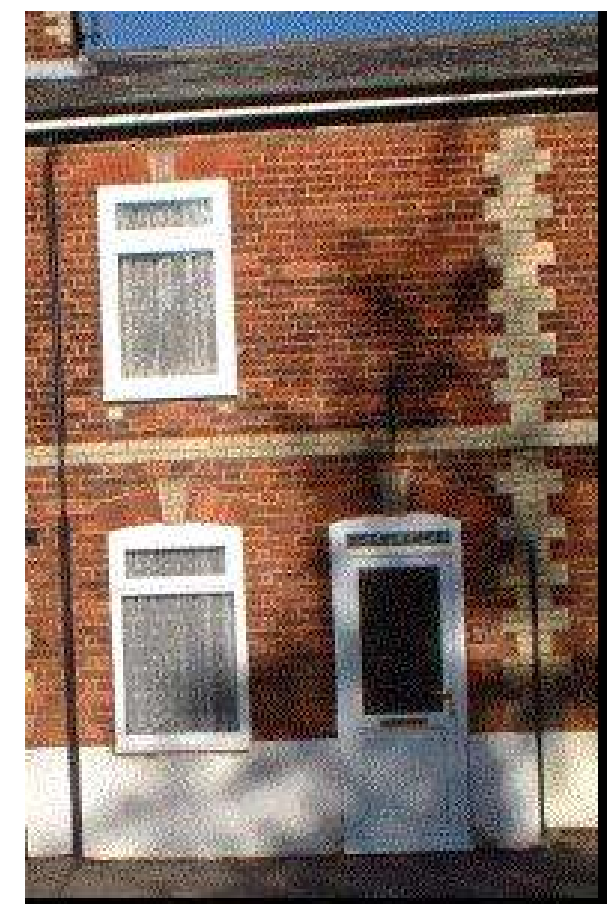

Figure 5. Front elevation of test house with new windows fitted. where,

$A_{t}=$ infiltration rate of house with vents (ach)

$\mathrm{T}=$ number of trickle vents,

$\mathrm{C}_{\mathrm{t}}=$ flow coefficient of vent,

$\mathrm{n}_{\mathrm{t}}=$ flow exponent of vent.

\section{Pilot Study}

In order to test the replacement window infiltration rate equation, a field study was carried out in a test house which was due to have its single glazed windows replaced by new double glazed units. The house was blower door tested (both pressurisation and depressurisation), with its original windows in place. The windows were then replaced and a second pressure test carried out. When the windows were removed care was taken to remove one window intact. This was then tested on a BS 5368 test rig to measure the flow coefficient and flow exponent. Using this data the replacement window infiltration rate equation was used to predict the change in infiltration. This prediction was then compared to the measured value. The test house was a mid terrace, 2 bedroom property with a volume of $173 \mathrm{~m}^{3}$. The original windows were single glazed with wooden frames; the new windows were double glazed with UPVC frames. The dimensions of the windows are given in Table 4.

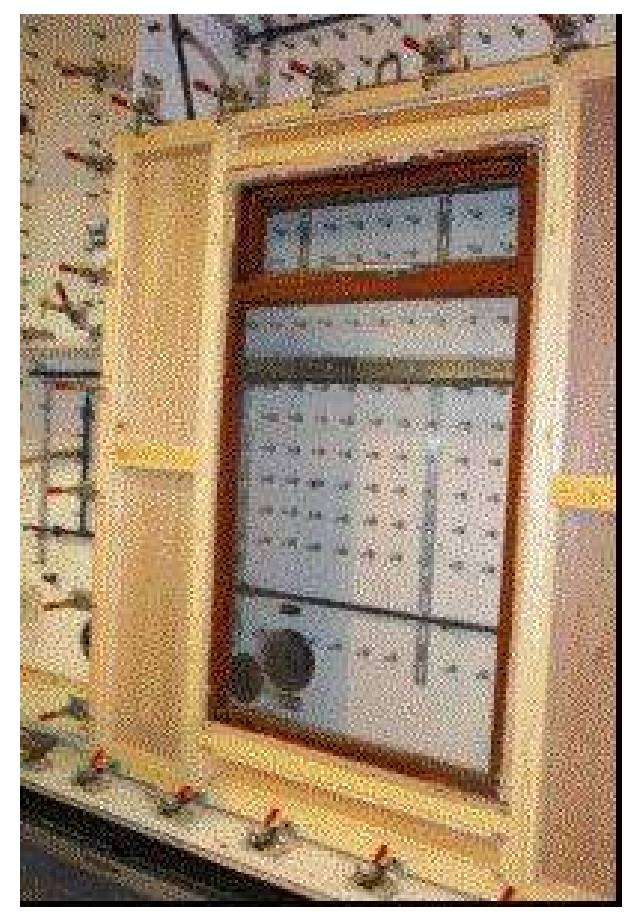

Figure 6. Old windows being tested in BS 5368 air permeability test rig 
Table 4. Perimeter dimensions of old and replacement windows

\begin{tabular}{|l|l|l|}
\hline & Total Perimeter of window $(\mathrm{m})$ & Perimeter of Opening $(\mathrm{m})$ \\
\hline Front1 (tested) & 4.61 & 2.2 \\
\hline Front2 & 4.61 & 2.2 \\
\hline Back1 & 4.34 & 5 \\
\hline Back2 & 4.71 & 5 \\
\hline Back3 & 2.31 & 2.2 \\
\hline
\end{tabular}

In total five windows and two doors were replaced. The window, from the lounge of the house was removed intact, and tested in a BS 5368 pressurisation rig, see Figure 6 . The flow coefficient of the old window was measured to be 0.0012 and the flow exponent 0.41 . It was only possible to test one window, hence it was assumed that all the old windows had similar flow characteristics, allowing for normalisation of opening perimeter, equal to that of the tested window. As the windows, which were removed, did not have identical dimensions to that of the single window, which was pressure tested, the value of $\mathrm{N}$, the number of windows replaced in the house was normalised using the perimeter of the opening lights. Hence removing the 5 actual windows was equivalent to replacing 8 pressure-tested windows.

Using Equation 14, and the measured values of $\mathrm{C}_{\mathrm{o}}$ and $\mathrm{n}_{0}$, the predicted change in background infiltration rate was calculated to be 0.05 ach.

When the house was pressure tested with it's original windows, the background infiltration rate was measured to be $0.34 \mathrm{ach}$. After replacement of the windows the new infiltration rate was measured to be $0.3 \mathrm{ach}$, a reduction of 0.04 ach or $12 \%$. There was therefore a good agreement between the predicted and measured decrease in infiltration rate.

Note: the blower door was mounted in the rear door of the house; hence this door did not contribute to the measured air infiltration of the house. The new front door was found to be badly fitted and was assumed to be as leaky as the door it replaced. It is assumed that all other sources of infiltration, including the gap between the window frames and the walls remained the same. The dimensions of the windows are given in Table 4.

\section{Conclusions and the Impact of Part $L$ of the Building Regulations}

A review of existing data suggests that replacing old leaky windows with modern sealed windows will reduce the background infiltration rate by the order of 0.1 ach to 0.3 ach. The actual value being dependent on the number of windows being replaced, the volume of the house and the leakiness of the old windows.

A new replacement window infiltration rate model has been developed and tested. The following example suggests that replacement windows can significantly reduce infiltration rates.

In a house with a floor area of $85 \mathrm{~m}^{2}$, the average for a post war house, with ceiling to floor height of 2.5 $\mathrm{m}$, and a volume of $212.5 \mathrm{~m}^{3}$. If each window has an area of $1 \mathrm{~m}^{2}$, the glazing to floor area ratio for a house with 10 windows is $11 \%$. Replacing 10 old windows which have a flow coefficient of $\mathrm{C}_{0}=$ 0.004, (value taken from AIVC, mean value of $\mathrm{C}_{\mathrm{o}}$ for unweatherstripped top hung timber frame casement windows), with modern well sealed units, would result in a change in infiltration rate of approximately $0.35 \mathrm{ach}$. If this property had an initial infiltration rate of $0.7 \mathrm{ach}$, the UK average, the new infiltration rate would be 0.35 ach, i.e. below the widely recommended level of $0.5 \mathrm{ach}$, to avoid problems due to moisture. The replacement of windows has therefore resulted in a ventilation regime that is significantly worse than that of the original state.

Some form of controllable background ventilation should be provided in dwellings which have an average or below average air infiltration in order to maintain a healthy indoor air quality. Using Equation 16 and pressure test results for an open trickle ventilator (Titon Select 4000 range $\mathrm{S} 13 / \mathrm{C} 13)$, the installation of 10 trickle ventilators into a house with a volume of $212 \mathrm{~m}^{3}$, would increase the background infiltration by approximately $0.15 \mathrm{ach}$. Therefore the resulting infiltration rate of the house with windows replaced and trickle ventilators open would be 0.5 ach.

It would appear that fitting well-sealed replacement windows to the average property in the UK might 


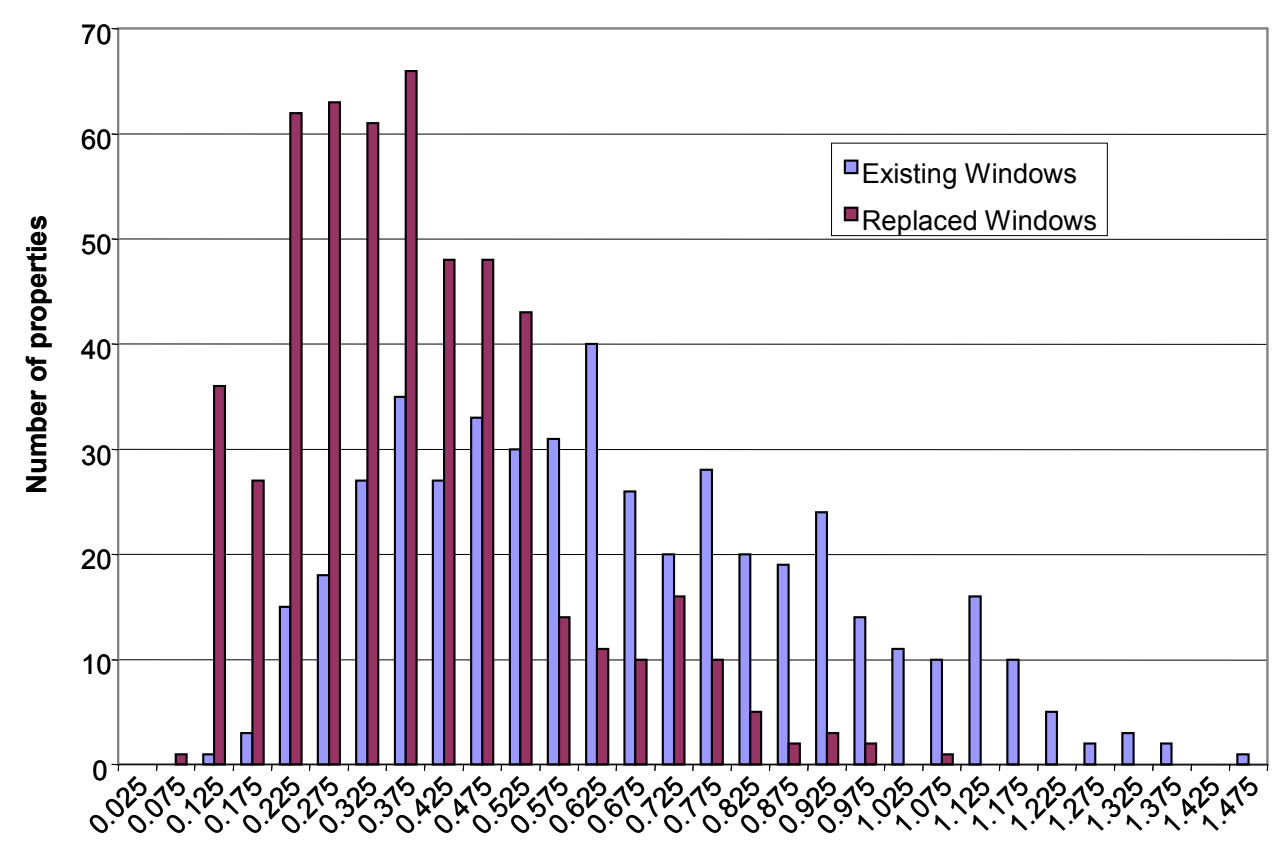

Air change rate (ach)

Figure 7 Distribution of air infiltration using BRE pressure test data before and after the installation of new windows, i.e. a $38 \%$ reduction in air infiltration up to a maximum of 0.35

reduce background ventilation rate by 0.25 ach. If we assume that the BRE pressure test data applies predominately to dwellings with old glazing and is typical of the UK building stock it is possible to use this data to make an estimate of the percentage of UK properties that would have a poor indoor air quality (i.e. below $0.5 \mathrm{ach}$ ) as a result of simply replacing old windows with new, assuming no additional controllable background ventilation is provided at the time of window replacement. If an average UK property $(0.75$ ach $)$ reduces its air change rate by $0.25 \mathrm{ach}$, this is a $0.38 \%$ reduction. Assuming that this percentage reduction applies to all the properties, this corrects for the fact that more airtight properties must already have relatively airtight windows. However, very leaky properties will not have this reduction in air tightness, a maximum reduction of 0.35 ach to such properties has therefore been assumed. If these assumptions are applied to the BRE pressure test data set, see Figure 7 , this results in $70 \%$ of dwellings having an air change rate of below 0.5 ach after the installation of new windows, whereas only $34 \%$ of properties were below 0.5 ach before new windows were introduced.

If moisture problems are to be avoided it is advisable that replacement windows be fitted with controllable background ventilation. The Building Regulations state "In addition the building should not have a worse level of compliance, after the work, with other applicable Parts of Schedule 1", it could be argued that a significant reduction in background ventilation, to a level below $0.5 \mathrm{ach}$, constitutes a worse level of compliance.

\section{Acknowledgements}

This work was undertaken while Jacquelyn Fox was employed at University College London as a TCS Associate with funding from the Department of Trade and Industry and Titon Hardware Plc.

\section{References}

American Society for Testing and Materials (1994): ASTM E783-93: "Test method for filed measurement of air leakage through installed exterior windows, curtain wall, and doors under specified pressure differences across the specimen." ASTM Standards, Vol 04.07 USA.

Anderson BR, Chapman PF, Cutland NG, Dickson CM, Doran SM, Iles PJ and Shorrock LD: (1997). "Bredem-8 Model Description." BRE 327. UK.

Axley JW: (1995) "New Mass Transport Elements and Components for the NIST IAQ Model". Yale Univ., New Haven, CT National Institute of Standards and Technology, Gaithersburg, MD. NIST GCR 95-676; 33 p. USA July 1995. 
BRECSU (1996) General Information Leaflet 9, "Domestic Ventilation." BRECSU UK.

BRECSU (1997) Good Practice guide 224, "Improving airtightness in existing homes". BRECSU UK

British Standard BS 5250:2002, "Code of practice for control of condensation in buildings". BSI UK. British Standard BS 5368 Part 1: "Test Method, Air permeability". BSI UK

CEN/TC 156 (2002) "Ventilation for buildings Performance testing of components/products for residential ventilation - Part 1: externally and internally mounted air transfer devices": $p r E N$ 13141-1(e) CEN

Hong S H, (2002). Personal communication. "Results of first year of monitoring: Warm Front project". University College London. UK

Liddament MW: (1986) “Air Infiltration Calculation Techniques- An Application Guide”. AIVC. UK.

Oreszczyn T, Pretlove S, (2000). "Mould Index". Chapter 9. Cutting the cost of Cold. Editors Rudge and Nicol. E \&FN Spon. UK.

Shapiro AM and James B (1997) "Creating Windows of Energy Saving Opportunity". Home Energy Magazine, Berkley USA, October

Sherman M, (1998) "The use of Blower Door Data" Lawrence Berkley Lab Report 35173. LLBL USA

Stephen RK: (1998) "Airtightness in UK dwellings: BRE's test results and their significance." Building Research Establishment, BRE 359. UK

The Building Regulations (2002a). "Approved document L1: Conservation of Fuel and Power in dwellings", 2002 edition. The Stationary Office HMSO UK
The Building Regulations (2002b). "Approved document F1: Means of Ventilation" 2002 edition. The Stationary Office HMSO UK.

Warren P: (2000). Technical Synthesis Report: "Multizone Air Flow Modelling (COMIS)" UK, Coventry, ESSU, AIVC UK

\section{Annex A}

Part L of the guidance for the 2002 Building Regulations for England and Wales states that the following should be undertaken: "Where windows are to be replaced, providing new draught-proofed ones either with an average $U$-value not exceeding the appropriate entry in Table 5 or with a centrepane $U$-value not exceeding $1.2 \mathrm{~W} / \mathrm{m}^{2} \mathrm{~K}$. Where Table 1 of the approved document states that for metal framed windows the U-value should be 2.2 $\mathrm{W} / \mathrm{m}^{2} \mathrm{~K}$ and for wood or PVC frames $2.0 \mathrm{~W} / \mathrm{m}^{2} \mathrm{~K}$. The higher $\mathrm{U}$-value for metal-framed windows allows for additional solar gain due the greater glazed proportion (The Building Regulations, 2002a).

The replacement work should comply with the requirements of Part L. In addition the building should not have a worse level of compliance, after the work, with other applicable Parts of Schedule 1.

Part L1 also refers to Part F of the Building Regulations under the heading of: "The requirement will be met if ventilation is provided which under normal conditions is capable (if used) of restricting the accumulation of such moisture (which could lead to mould growth) and pollutants originating within a building as would otherwise become a hazard to the health of the people in the building." (The Building Regulations 2002b)

The recommendations of Table 1 of the approved document Part F are given below in Table A1

Table A1. Table 1 of the approved document Part F recommends the following:

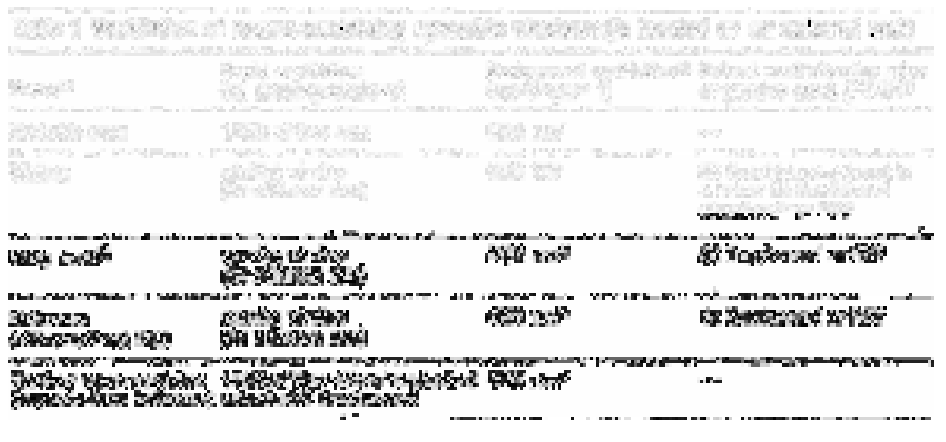

